\title{
RISIKO OSTEOPOROSIS DI INDONESIA
}

\author{
Abas Basuni Jahari' dan Sri Prihatini ${ }^{1}$ \\ 'Puslitbang Gizi dan Makanan Depkes RI, Bogor
}

\section{ABSTRACT}

\section{RISK OF OSTEOPOROSIS IN INDONESIA}

Background: Osteoporosis is on of growing problems in the world which is related to ageing process. It is estimated that in the year 2050 around $50 \%$ bone fracture in Asia is associated with osteoporosis. However, epidemiological information about osteoporosis in Indonesia is still rarely available.

Objective: To provide information on the magnitude of osteoporosis in Indonesia.

Method: In 1999 and 2003-2005 PT FBI carried free Bone Mineral Density (BMD) examination in several provinces of Indonesia. The total samples of 126,265 subjects were those who came to the examination center set by the PT FBI. The equipment used to examine BMD is "Sahara Clinical Bone Sonometer".

Results: It is found that the proportion of risk of osteoporosis was 19.7 percent in 2002, 7.7 percent in 2003, 7.0 percent in 2004 and 10.7persen in 2005. The pattern of the problem was similar from 2002 to 2005; the risk of osteoporosis is increasing following the ages. The proportion of osteophenia was higher than that of risk of osteoporosis. The proportion of osteophenia was 36.0 percent in 2002, 46.8 percent in 2003, 46.5 percent in 2004 and 41.8 percent in 2005. The proportion of risk of osteoporosis below 55 years of age was less in male than in female, however in the age of $>=55$ years the proportion was higher in female than in male subjects.

Conclusion: The proportion of risk of osteoporosis was less in 2005 than that in 2002. However, this figure is not an indication of decreasing problem of risk of osteoporosis, because the nature of the population distribution and sampling method did not provide evidence of representativeness for the areas. The problem of ostephenia relatively did not change much from 36.0 percent in 2002 to 41.8 percent in 2005 or around 40 percent. This means that four out of 10 elderly having risk of developing osteoporosis.

Recommendation: Problem of osteoporosis should be taken care not only for older people but should start from the younger age. To obtain more representative figures on osteoporosis a more appropriate designed study needs to be carried out.

Keywords: osteoporosis, osteophenia, bone mineral density

\section{PENDAHULUAN}

O steoporosis merupakan masalah yang berkaitan dengan proses penuaan, oleh karena itu ancaman masalah osteoporosis terjadi tidak hanya di negara berkembang tetapi juga di negara maju. Osteoporosis merupakan faktor utama keretakan pada paha, tulang belakang dan pergelangan tangan. Saat kini sekitar 10 juta penduduk di Amerika saat diperkirakan menderita osteoporosis dan ada 18 juta lainnya memiliki massa tulang yang rendah.
Perubahan demografis dalam 50 tahun mendatang akan mengakibatkan meningkatnya jumlah perduduk lanjut umur di negara berkembang, dengan demikian jumlah penderita retak tulang diperkirakan akan meningkat secara signifikan .

Osteoporosis juga dikenal sebagai suatu penyakit yang tidak dirasakan ("silent disease") karena kejadian penurunan massa tulang dapat terjadi bertahun-tahun tanpa disertai tanda-tanda (symptom). Beberapa symptom hanya dapat dikenali bila sudah mencapai tahap lanjut. Penurunan massa 
tulang biasanya disertai dengan rasa sakit pada leher dan tulang. Symptom yang paling umum pada osteoporosis adalah retak /patah tulang, tubuh bungkuk, tinggi badan berkurang, dan sakit punggung. Satu di antara dua wanita dan satu di antara delapan laki-laki umur 50 tahun atau lebih menderita retak tulang yang disebabkan karena osteoporosis dalam kehidupannya ${ }^{(1)}$.

Data epidemiologis tentang besaran masalah osteoporosis di Indonesia masih sangat langka. Perubahan demografis di Indonesia pada dekade yang lalu membawa akibat meningkatnya umur harapan hidup dan diharapkan akan banyak penduduk lanjut umur di dekade mendatang. Oleh karena itu, tersedianya infornasi tentang besaran masalah osteoporosis menjadi penting dalam rangka mencegah penduduk dari risiko osteoporosis.

Dalam rangka memahami besaran masalah risiko osteoporosis, pada tahun 1999 PT FBI telah melakukan pemeriksaan Densitas Mineral Tulang (DMT) terhadap 17000 penduduk di 14 propinsi di Indonesia. Data kemudian diolah pada tahun 2002 yang hasilnya menunjukkan bahwa sebanyak 19,7 persen memiliki risiko osteoporosis. Untuk mengetahui gambaran selanjutnya tentang besaran masalah osteoporosis di Indonesia PT FBI melakukan pemeriksaan DMT secara berkala mulai tahun 2003 sampai 2005. Data hasil pemeriksaan tersebut diolah dan dianalisis oleh Pusat Penelitian dan Pengembangan Gizi dan Makanan. Departemen Kesehatan $\mathrm{RI}$ di Bogor bekerjasama dengan PT FBI.

\section{Tujuan}

Untuk memberikan gambaran berkala tentang besaran masalah risiko osteoporosis di Indonesia menurut tahun pemeriksaan ( tahun 2002, 2003, 2004 dan 2005).

\section{BAHAN DAN CARA}

\section{Data dan Lokasi}

Data yang digunakan dalam analisis ini berasal dari hasil pemeriksaan DMT yang dilakukan oleh PT FONTERRA BRANDS
INDONESIA di 14 propinsi di Indonesia pada tahun 1999 (diolah tahun 2002) dan pada tahun 2003 - 2005 di 16 provinsi .

\section{Sampel dan Besar Sampel}

Sampel dalam kegiatan tahun 2003 2005 adalah mereka yang secara sukarela memeriksakan kalsium darah dan kepadatan masa tulang di outlet demo-promosi PT FBI di Mall, swalayan dan di instansi swasta maupun pemerintah secara gratis. Sedangkan sampel tahun 2002 adalah mereka yang datang membeli produk susu tinggi kalsium di lokasi demo-promosi PT New Zealand, sehingga jumlah sampel tahun 2002 sekitar setengah jumlah sampel tahun 2005. Dalam pengumpulan data, sampel tidak dirancang untuk mewakili wilayah tertentu.

\section{Data Yang Dikumpulkan}

Data yang dikumpulkan adalah Densitas Mineral Tulang (DMT) menggunakan alat "Sahara Clinical Bone Sonometer" dan data identitas sampel, meliputi alamat tempat tinggal, jenis kelamin, tanggal lahir/umur.

\section{Manajemen Data dan Analisis}

Data hasil pemeriksaan DMT dimasukkan ke komputer oleh PT FBI menggunakan program Excel. Data mentah (raw data) diserahkan kepada Pusat Penelitian dan Pengembangan Gizi dan Makanan untuk selanjutnya dilakukan pembersihan data (data cleaning), penyeragaman struktur file dari tiap lokasi pemeriksaan, pemberian kode untuk tiap lokasi pemeriksaan, pengelompokan umur, dan penilaian status osteoporosis. Data Skor-T sebagai dasar untuk menilai status risiko osteoporosis sudah ada dari hasil pemeriksaan.

Skor-T adalah perbedaan antara hasil pemeriksaan sampel dengan nilai rata-rata populasi rujukan, yang disajikan dalam unit standar deviasi dari populasi rujukan muda umur 7 ("User's Guide of Sahara Bone Sonometer").

$$
\begin{aligned}
& \text { Skor- } \mathbf{T}=(\mathbf{P}-\mathbf{Y A}) / \text { SDYA } \\
& \mathrm{P} \quad=\text { hasil pemeriksaan sampel }
\end{aligned}
$$


Y A = Nilai rata-rata populasi rujukan muda umur

SDYA = Standar deviasi populasi rujukan muda umur

Seseorang dengan nilai Skor-T kurang dari -2.0 SD dikategorikan memiliki risiko osteoporosis, antara -1.0 SD dan -2.0 SD dikategorikan sebagai osteopenia. Oleh karena sebaran nilai Skor-T mengikuti sebaran Gaussian (sebaran normal), maka secara statistik di dalam populasi yang normal terdapat sebanyak 2,5 persen penduduk yang memiliki risiko osteoporosis $^{(2)}$.

Tabel 1

Data Rujukan Hasil Estimasi SAHARA Menurut Umur yang digunakan dalam analisis data Densitas Mineral Tulang (DMT)

\begin{tabular}{|c|c|c|}
\hline Umur ( tahun) & Perkiraan DMT $\left(\mathrm{g} / \mathrm{cm}^{2}\right)$ & Standar deviasi $\left(\mathrm{g} / \mathrm{cm}^{2}\right)$ \\
\hline 25 & 0,581 & 0,112 \\
35 & 0,555 & 0,112 \\
45 & 0,562 & 0,112 \\
55 & 0,545 & 0,112 \\
65 & 0,471 & 0,112 \\
75 & 0,436 & 0,112 \\
85 & 0,373 & 0,112 \\
95 & 0,339 & 0,112 \\
\hline
\end{tabular}

\section{HASIL}

\section{Jumlah sampel}

Jumlah seluruh sampel mulai tahun 2002 - 2005 adalah sebanyak 126.265 orang, yaitu sekitar 32,3 persen laki-laki dan
67,7 persen perempuan. Ternyata setiap tahunnya jumlah sampel perempuan terlihat selalu lebih banyak dari sampel laki-laki, yaitu lebih dari 65 persen (lihat tabel 2).

Tabel 2

Sebaran Jumlah Sampel Menurut Tahun Pemeriksaan dan Jenis Kelamin

\begin{tabular}{|c|c|c|c|c|c|c|}
\hline \multirow{2}{*}{ Tahun } & \multicolumn{2}{|c|}{ Laki-laki } & \multicolumn{2}{c|}{ Perempuan } & \multicolumn{2}{c|}{ Total } \\
\cline { 2 - 7 } & $\mathrm{N}$ & $\%$ & $\mathrm{~N}$ & $\%$ & $\mathrm{~N}$ & $\%$ \\
\hline 2002 & 5154 & 29.7 & 12206 & 70.3 & 17360 & 100.0 \\
\hline 2003 & 3346 & 29.5 & 7980 & 70.5 & 11326 & 100.0 \\
\hline 2004 & 9491 & 29.8 & 22361 & 70.2 & 31852 & 100.0 \\
\hline 2005 & 22799 & 34.7 & 42928 & 65.3 & 65727 & 100.0 \\
\hline TOTAL & 40790 & 32.3 & 85478 & 67.7 & 126265 & 100.0 \\
\hline
\end{tabular}

Dari sebaran sampel menurut lokasi pemeriksaan dari tahun 2002 sampai tahun 2005 terlihat tidak merata. Pada tahun 2002 sebagian besar sampel berasal dari 12 lokasi, pada tahun 2003 dari 10 lokasi, pada tahun 2004 dari 7 lokasi, dan pada tahun 2005 dari 15 lokasi pemeriksaan. Jumlah penduduk yang diperiksapun menjadi lebih banyak pada tahun 2005 yaitu sekitar 3 kali lebih banyak dari tahun 2002. Berdasarkan 
hal ini maka jumlah penduduk yang memiliki resiko osteoporosis dari tahun ke tahun tidak dapat dijadikan dasar tentang gambaran perubahan penderita tetapi merupakan gambaran pola besaran masalah menurut umur dan jenis kelamin.

Tabel 3

Sebaran Sampel Menurut Lokasi Pemeriksaan dan Tahun Pemeriksaan

\begin{tabular}{|c|c|c|c|c|}
\hline Lokasi Pemeriksaan & 2002 & 2003 & 2004 & 2005 \\
\hline Sumatra Utara, NAD & 485 & 773 & 11 & 7569 \\
\hline Sumatra Barat & 0 & 572 & 5 & 3155 \\
\hline Riau & 162 & 126 & 4 & 4033 \\
\hline Kepulauan Riau & 0 & 0 & 0 & 1614 \\
\hline Jambi & 0 & 8 & 3 & 1456 \\
\hline Sumsel, Babel, Bengkulu & 166 & 4 & 9 & 1655 \\
\hline Lampung & 399 & 311 & 5 & 1254 \\
\hline DKI Jakarta & 5671 & 21 & 738 & 1178 \\
\hline Banten & 597 & 1470 & 5207 & 5111 \\
\hline Jawa Barat & 2528 & 855 & 5892 & 11791 \\
\hline Jawa Tengah & 2503 & 2182 & 6898 & 8592 \\
\hline DI Yogyakarta & 907 & 9 & 965 & 1604 \\
\hline Jawa Timur & 2255 & 2099 & 9966 & 9539 \\
\hline Bali, NTB, NTT & 410 & 4 & 2119 & 3152 \\
\hline Kalimantan & 1277 & 1041 & 18 & 5 \\
\hline Sulawesi, Maluku \& Papua & 0 & 1851 & 12 & 4019 \\
\hline TOTAL & 17360 & 11326 & 31852 & 65727 \\
\hline
\end{tabular}

Besaran Masalah Risiko Osteoporosis Menurut Kelompok Umur dan Jenis Kelamin

Gambaran distribusi sampel menurut kelompok umur dan jenis kelamin pada tahun 2002 disajikan pada Tabel 4 dan Gambar 1.

Pada tahun 2002 tidak terdapat sampel umur dibawah 25 tahun. Tetapi sejak pengukuran tahun 2003 terdapat sampel dengan umur di bawah 25 tahun dan jumlahnya cukup banyak yaitu hampir 13 ribu orang. Proporsi risiko osteoporosis pada tahun 2002 adalah sebesar 14,8 persen pada laki-laki dan 21,7 persen pada perempuan. Proporsinya terlihat rendah pada umur muda dan meningkat pada umur yang lebih tua. Bila dilihat menurut jenis kelamin, pada laki-laki proporsinya lebih rendah yaitu 14,8 persen dibandingkan dengan perempuan yaitu 21,7 persen. Baik pada laki-laki maupun perempuan polanya 
terlihat sama proporsinya mulai meningkat pada umur 45 tahun.

Tabel 4

Distribusi Sampel Laki-laki dan Perempuan Menurut Kelompok Umur dan Status Osteoporosis Tahun 2002

\begin{tabular}{|c|c|c|c|c|}
\hline \multirow{2}{*}{$\begin{array}{c}\text { Umur } \\
\text { (tahun) }\end{array}$} & \multicolumn{4}{|c|}{ Status Osteoporosis } \\
\cline { 2 - 5 } & \multicolumn{2}{|c|}{ Osteoporosis } & \multicolumn{2}{c|}{ Osteopenia } \\
\cline { 2 - 5 } & Laki-laki & Perempuan & Laki-laki & Perempuan \\
\hline $25-29$ & 5.4 & 5.4 & 28.1 & 28.0 \\
\hline $30-34$ & 7.4 & 6.2 & 36.7 & 30.4 \\
\hline $35-39$ & 8.8 & 6.2 & 39.2 & 32.0 \\
\hline $40-44$ & 10.5 & 7.7 & 40.9 & 34.3 \\
\hline $45-49$ & 12.6 & 12.2 & 40.6 & 36.6 \\
\hline $50-54$ & 13.8 & 20.8 & 40.6 & 40.6 \\
\hline $55-59$ & 20.0 & 36.1 & 38.9 & 43.0 \\
\hline $60-64$ & 23.6 & 51.8 & 46.0 & 33.5 \\
\hline $65-69$ & 29.4 & 63.0 & 40.8 & 27.9 \\
\hline $70+$ & 42.4 & 71.8 & 35.7 & 22.0 \\
\hline TOTAL & 14.8 & 21.7 & 39.1 & 34.7 \\
\hline
\end{tabular}

Gambar 1. Proporsi Laki-laki dan Perempuan Dewasa Penderita Resiko Osteoporosis Menurut Kelompok Umur Pada Tahun 2002

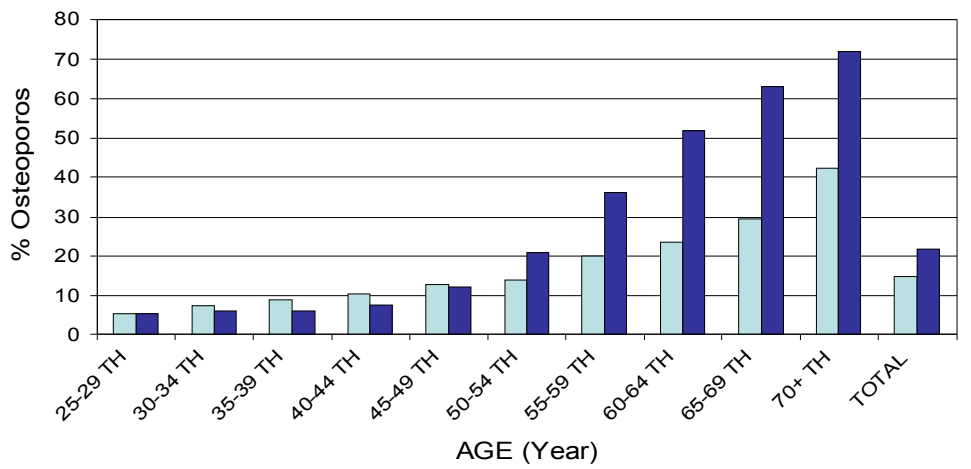

$\square$ Laki-laki $\square$ Perempuan

Gambaran distribusi sampel menurut kelompok umur dan jenis kelamin pada tahun 2003 disajikan pada Tabel 5 dan Gambar 2. Pada tahun 2003 proporsi risiko osteoporosis adalah sebesar 7,7 persen.
Berbeda dengan tahun 2002, proporsinya mulai terlihat meningkat pada umur 45 tahun, sedangkan pada tahun 2003 proporsinya mulai meningkat pada umur 55 tahun. 
Proporsi osteoporosis pada laki-laki ternyata lebih tinggi yaitu sebesar 8,1 persen dibandingkan pada perempuan, yaitu sebesar 7,6 persen. Fakta ini menunjukkan bahwa lebih banyak laki-laki yang menderita osteoporosis dari pada perempuan. Padahal secara fisiologis wanita mempunyai risiko lebih tinggi untuk menderita osteoporosis dibandingkan dengan laki-laki. Pada umur di atas 59 tahun proporsi pada perempuan terlihat lebih tinggi dari laki-laki.

Tabel 5

Distribusi Sampel Laki-laki dan Perempuan Menurut Kelompok Umur dan Status Osteoporosis Tahun 2003

\begin{tabular}{|c|c|c|c|c|}
\hline \multirow{2}{*}{$\begin{array}{c}\text { Umur } \\
\text { (tahun) }\end{array}$} & \multicolumn{4}{|c|}{ Status Osteoporosis } \\
\cline { 2 - 5 } & \multicolumn{2}{|c|}{ Osteoporosis } & \multicolumn{2}{c|}{ Osteopenia } \\
\cline { 2 - 5 } & Laki-laki & Perempuan & Laki-laki & Perempuan \\
\hline$<25$ & 0.7 & 0.5 & 40.6 & 27.1 \\
\hline $25-29$ & 2.4 & 0.3 & 44.5 & 31.0 \\
\hline $30-34$ & 1.8 & 0.9 & 46.6 & 34.8 \\
\hline $35-39$ & 2.3 & 0.7 & 50.0 & 38.0 \\
\hline $40-44$ & 5.5 & 1.3 & 54.0 & 38.6 \\
\hline $45-49$ & 5.7 & 1.5 & 54.8 & 42.2 \\
\hline $50-54$ & 6.0 & 5.6 & 56.7 & 51.8 \\
\hline $55-59$ & 12.3 & 13.8 & 57.5 & 61.2 \\
\hline $60-64$ & 12.8 & 21.4 & 57.1 & 64.2 \\
\hline $65-69$ & 22.7 & 33.1 & 58.9 & 54.7 \\
\hline $70+$ & 36.3 & 46.6 & 50.5 & 46.6 \\
\hline TOTAL & 8.1 & 7.6 & 52.4 & 44.4 \\
\hline
\end{tabular}

Gambar 2. Proporsi Laki-laki dan Perempuan Dewasa Penderita Resiko Osteoporosis Menurut Kelompok Umur Pada Tahun 2003

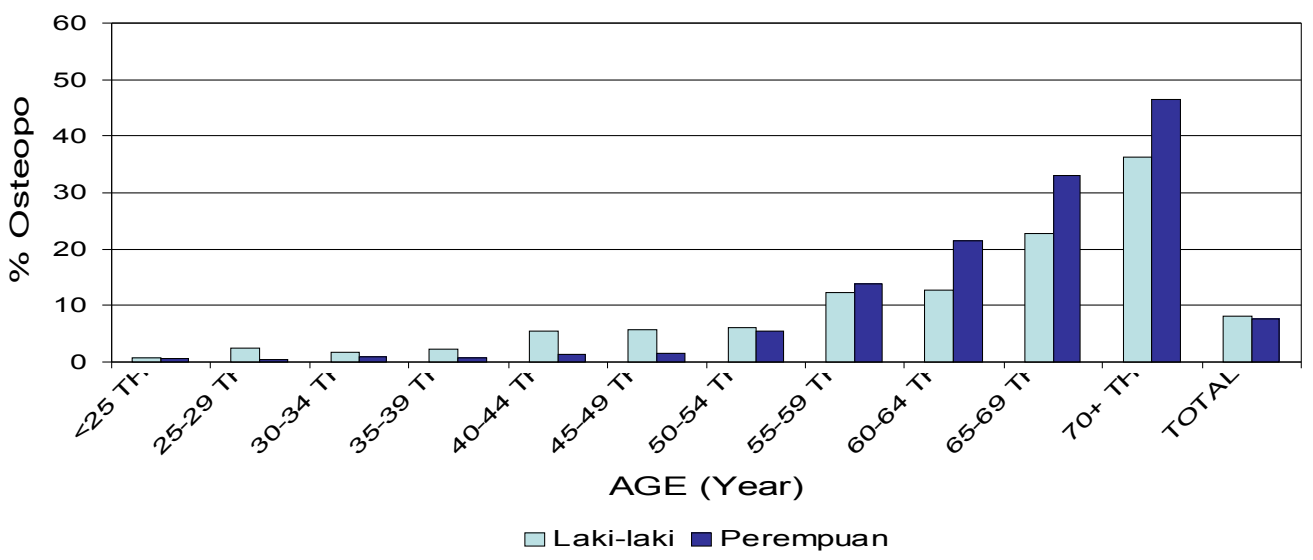


Gambaran distribusi sampel menurut kelompok umur dan jenis kelamin pada tahun 2004 disajikan pada Tabel 6 dan Gambar 3. Pada tahun 2004 proporsi risiko osteoporosis adalah sebesar 7 persen, yaitu sebesar 8,9 persen pada laki-laki dan hanya 6,3 persen pada perempuan. Mirip dengan pola pada tahun tahun sebelumnya, proporsi osteoporosis lebih tinggi pada laki-laki pada umur muda. Pada tahun 2004 proporsi yang tinggi pada laki-laki sampai umur 55-59 tahun, setelah umur itu secara konsisten proporsi osteoporosis pada wanita lebih tinggi dari laki-laki. Terdapat perbedaan yang mencolok antara laki-laki dan perempuan di atas umur 64 tahun. Pada umur 65-69 proporsi pada wanita lebih tinggi 12 persen dari laki-laki dan pada umur 70 tahun keatas perbedaan mendekati 19 persen.

Tabel 6

Distribusi Sampel Laki-laki dan Perempuan Menurut Kelompok Umur dan Status Osteoporosis Tahun 2004

\begin{tabular}{|c|c|c|c|c|}
\hline \multirow{2}{*}{$\begin{array}{c}\text { Umur } \\
\text { (tahun) }\end{array}$} & \multicolumn{4}{|c|}{ Status Osteoporosis } \\
\cline { 2 - 5 } & \multicolumn{2}{|c|}{ Osteoporosis } & \multicolumn{2}{c|}{ Osteopenia } \\
\cline { 2 - 5 } & Laki-laki & Perempuan & Laki-laki & Perempuan \\
\hline$<25$ & 2.6 & 0.2 & 36.2 & 26.0 \\
\hline $25-29$ & 1.9 & 0.9 & 45.3 & 31.7 \\
\hline $30-34$ & 4.2 & 0.9 & 49.7 & 37.5 \\
\hline $35-39$ & 5.5 & 1.1 & 51.4 & 39.4 \\
\hline $40-44$ & 6.2 & 1.3 & 51.2 & 40.1 \\
\hline $45-49$ & 7.2 & 2.6 & 56.5 & 44.9 \\
\hline $50-54$ & 9.2 & 5.2 & 57.2 & 54.0 \\
\hline $55-59$ & 13.3 & 12.3 & 55.1 & 63.4 \\
\hline $60-64$ & 15.0 & 22.2 & 59.2 & 60.4 \\
\hline $65-69$ & 22.2 & 34.1 & 57.2 & 55.8 \\
\hline $70+$ & 32.3 & 51.8 & 53.0 & 40.8 \\
\hline TOTAL & 8.9 & 6.3 & 52.8 & 43.9 \\
\hline
\end{tabular}


Gambar 3. Proporsi Laki-laki dan Perempuan Dewasa Penderita Resiko

Osteoporosis Menurut Kelompok Umur Pada Tahun 2004

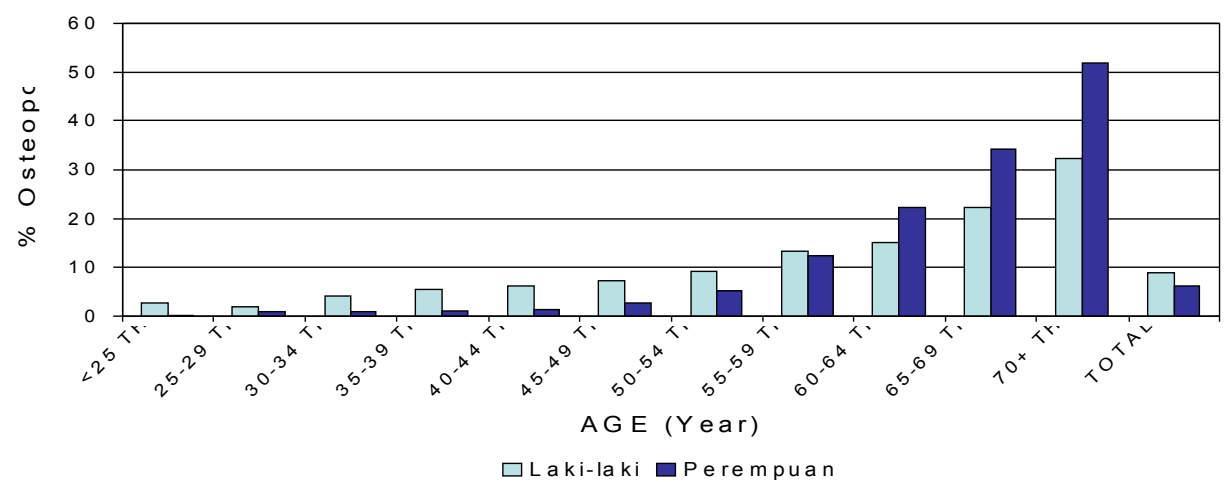

Gambaran distribusi sampel menurut kelompok umur dan jenis kelamin pada tahun 2005 disajikan pada Tabel 7 dan Gambar 4. Proporsi risiko osteoporosis pada tahun 2005 terlihat lebih tinggi dari tahun 2003 dan tahun 2004, yaitu sebesar 10,3 persen. Sama dengan tahun 2003 dan tahun 2004, ternyata proporsi risiko osteoporosis pada laki-laki tetap terlihat lebih tinggi yaitu sebesar 14,3 persen dan pada perempuan sebesar 8,2 persen. Pada tahun 2005, tampak sampai umur 55-59 proporsi osteoporosis pada laki-laki masih lebih tinggi dari wanita, namun pada umur diatas itu proporsi osteoporosis pada wanita lebih tinggi dari laki-laki.

Tabel 7

Distribusi Sampel Laki-laki dan Perempuan Menurut Kelompok Umur dan Status Osteoporosis Tahun 2005

\begin{tabular}{|c|c|c|c|c|}
\hline \multirow{2}{*}{$\begin{array}{c}\text { Umur } \\
\text { (tahun) }\end{array}$} & \multicolumn{4}{|c|}{ Status Osteoporosis } \\
\cline { 2 - 5 } & \multicolumn{2}{|c|}{ Osteoporosis } & \multicolumn{2}{c|}{ Osteopenia } \\
\cline { 2 - 5 } & Laki-laki & Perempuan & Laki-laki & Perempuan \\
\hline$<25$ & 5.9 & 2.9 & 41.4 & 35.7 \\
\hline $25-29$ & 8.4 & 4.1 & 45.1 & 36.5 \\
\hline $30-34$ & 11.8 & 4.6 & 47.5 & 38.0 \\
\hline $35-39$ & 12.9 & 5.7 & 46.8 & 38.0 \\
\hline $40-44$ & 13.5 & 5.7 & 48.6 & 37.2 \\
\hline $45-49$ & 15.9 & 7.4 & 51.2 & 39.4 \\
\hline $50-54$ & 19.2 & 11.9 & 50.4 & 46.1 \\
\hline $55-59$ & 22.2 & 21.0 & 48.9 & 47.7 \\
\hline $60-64$ & 27.7 & 30.4 & 51.5 & 48.7 \\
\hline $65-69$ & 32.3 & 39.2 & 49.9 & 47.1 \\
\hline $70+$ & 43.6 & 58.9 & 39.8 & 32.5 \\
\hline TOTAL & 14.3 & 8.2 & 47.4 & 38.8 \\
\hline
\end{tabular}


Gambar 4. Proporsi Laki-laki dan Perempuan Dewasa Penderita Resiko Osteoporosis Menurut Kelompok Umur Pada Tahun 2005

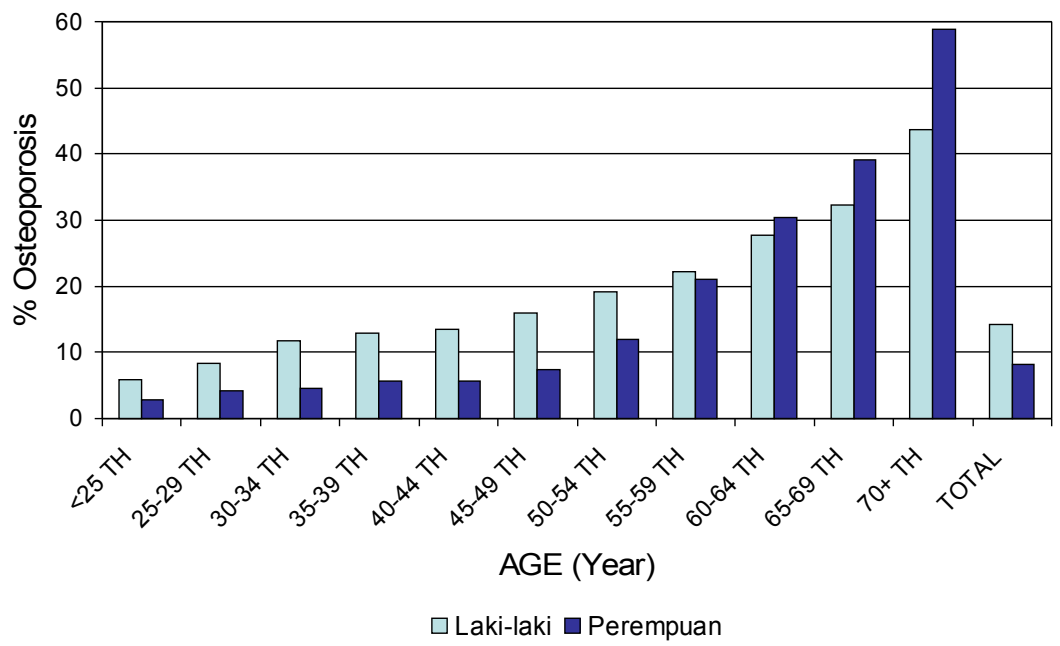

Bila dilihat proporsinya menurut prevalensi osteoporosis pada laki-laki lebih kelompok umur terdapat kecenderungan tinggi dari perempuan, tetapi setelah umur itu pola yang sama, yaitu rendah pada umur muda dan meningkat pada umur yang lebih tua. Pada tahun 2002 dan 2005, proporsi rendah sampai umur 44 tahun kemudian meningkat setelah umur itu. Tetapi pada tahun 2003 dan 2004, proporsinya terlihat meningkat mulai umur 54 tahun.

Seperti gambaran pada tahun 20032005, dapat dilihat bahwa sejak umur muda (< 25 tahun) sampai umur 50-54 tahun, prevalensinya lebih tinggi pada perempuan.

\section{Besaran Masalah Risiko Osteoporosis menurut Tahun Pemeriksaan}

Gambaran prevalensi osteoporosis dari tahun 2002 sampai tahun 2005 disajikan pada Tabel 12. Prevalensi osteoporosis tertinggi terlihat pada tahun 2002 yaitu 19,7 persen dan terendah pada tahun 2004 yaitu 7,0 persen.

Tabel 8

Penderita Osteoporosis Menurut Tahun Pemeriksaan

\begin{tabular}{|c|c|c|c|c|c|c|c|c|}
\hline \multirow{2}{*}{$\begin{array}{c}\text { Tahun } \\
\text { pemeriksaan }\end{array}$} & \multicolumn{6}{|c|}{ Status Osteoporosis } & \multicolumn{2}{|c|}{ Jumlah } \\
\cline { 2 - 9 } & \multicolumn{2}{|c|}{ Osteoporosis } & \multicolumn{2}{|c|}{ Osteopenia } & \multicolumn{2}{c|}{ Normal } & \multicolumn{2}{c|}{} \\
\cline { 2 - 9 } & $\mathrm{n}$ & persen & $\mathrm{n}$ & persen & $\mathrm{n}$ & persen & $\mathrm{n}$ & persen \\
\hline Tahun 2002 & 3417 & 19.7 & 6247 & 36.0 & 7696 & 44.3 & 17360 & 100.0 \\
\hline Tahun 2003 & 877 & 7,7 & 5296 & 46,8 & 5153 & 45,5 & 11326 & 100.0 \\
\hline Tahun 2004 & 2243 & 7,0 & 14826 & 46,5 & 14783 & 46,4 & 31852 & 100.0 \\
\hline Tahun 2005 & 6789 & 10,3 & 27475 & 41,8 & 31463 & 47,9 & 65727 & 100.0 \\
\hline
\end{tabular}




\section{BAHASAN}

Hasil analisis data dari tahun 2002 sampai tahun 2005 menunjukkan bahwa proporsi risiko osteoporosis tertinggi terlihat pada tahun 2002 yaitu 19,7 persen dan terendah pada tahun 2004 yaitu 7,0 persen. Gambaran ini tidak dapat dibandingkan antar tahun karena pengambilan sampelnya berbeda dan jumlah yang diperiksa juga tidak sebanding.. Pada tahun 2002, sampel yang diukur adalah mereka yang datang membeli produk susu tinggi kalsium sedangkan pada tahun 2005, sampel adalah mereka yang datang secara sukarela dan diperiksa secara gratis pada demo promosi PT FBI. Sehingga jumlah sampel pada tahun 2005 meningkat menjadi hampir 4 kali lipat dibandingkan jumlah sampel tahun 2002. Sedangkan proporsi risiko osteopenia mulai tahun 2002 sampai 2005 terlihat relatif tidak berubah yaitu 36,0 persen tahun 2002 , 46,8 persen tahun $2003,46,5$ persen tahun 2004 dan 41,8 persen tahun 2005. Hal ini berarti bahwa 4 dari 10 orang mempunyai risiko osteopenia

Pada tahun 2002, proporsi risiko osteoporosis lebih tinggi pada perempuan, sedangkan pada tahun 2003 - 2005 proporsinya lebih tinggi pada laki-laki. Kemudian pola yang sama juga menunjukkan bahwa sampai umur 55 tahun, proporsinya lebih tinggi pada laki-laki dan pada setelah umur 55 tahun proporsinya lebih tnggi pada perempuan. Tingginya proporsi pada laki-laki sebelum umur 55 tahun kemungkinan berkaitan dengan gaya hidup seperti kebiasaan merokok, minum alkohol, minum kopi dan jarang melakukan olah raga ${ }^{(4,6,7)}$. Namun pada analisis ini, data mengenai faktor risiko tidak ada. Kemudian tingginya proporsi risiko osteoporosis pada perempuan setelah umur 55 tahun adalah disebabkan karena kejadian retak tulang pada perempuan berhubungan erat dengan perubahan metabolisme tulang pada umur post-menopause. Menopause adalah masa transisi pada kehidupan wanita dimana ovarium berhenti memproduksi telur, aktivitas menstruasi menurun dan terkadang berhenti, dan kemampuan tubuh memproduksi hormon estrogen dan progesteron menurun. Dalam keadaan normal menopause terjadi pada umur 40 sampai 55 tahun. Menurunnya hormon estrogen meningkatkan risiko terjadinya osteoporosis yang sering tidak diketahui sampai terjadinya keretakan tulang ${ }^{(1,3)}$. Dalam menjalani proses penuaan, wanita membutuhkan cukup kalsium, makanan dengan jumlah kalsium yang memadai menjadi penting. Wanita pasca-menopause membutuhkan sekitar 1200-1500 mg kalsium per hari ${ }^{(5,8)}$. Suplemen estrogen dapat membantu pencegahan osteoporosis pada wanita pasca-menopause.

\section{KESIMPULAN}

\section{Kesimpulan}

1. Pada tahun 2002 proporsi risiko osteoporosis adalah 19,7 persen. yaitu pada laki-laki 14,8 persen dan perempuan 21,7 persen. Pada tahun 2003, sebesar 7,7 persen, kemudian sebesar 7 persen tahun 2004 dan tahun 2005 sebesar 10,3 persen yaitu laki-laki 14,3 persen dan perempuan sebesar 8,2 persen. Namun hal ini belum dapat dikatakan terjadi penurunan karena sampel yang diukur berbeda dalam sebaran lokasi maupun cara pemilihannya.

2. Sampai dengan umur 55 tahun, proporsi risiko osteoporosis lebih tinggi pada laki-laki dan setelah umur 55 tahun proporsinya lebih tingi pada wanita.

3. Pada tahun 2005 proporsi risiko osteopenia sebesar 41,8 persen atau 4 dari 10 penduduk memiliki risiko osteoporosis, suatu keadaan yang harus mendapat perhatian dalam upaya pencegahan atau mengurangi risiko osteoporosis pada usia-usia rentan.

\section{Saran}

1. Dalam rangka upaya meningkatkan keadaan kesehatan dan gizi penduduk di dalam rantai siklus kehidupan, maka penanganan masalah osteoporosis 
sudah harus mendapat perhatian mulai dari usia dini.

2. Untuk memperoleh gambaran masalah osteoporosis dan faktor risiko (determinan) nya yang lebih mewakili keadaan suatu wilayah, perlu dilakukan kajian atau studi dengan menggunakan prosedur sampling yang sesuai.

\section{RUJUKAN}

1. Sankaran, B. Osteophorosis: Clinical, Radiological, Histological, Assessment and an Experimental Study. A publication funded by South-east Asia Regional Office, WHO, India, :WOO.

2. SAHARA Clinical Bone Sonometer. Advanced Clinical Bone Sonometer User's Guide. Document No. 080-0689 Revision A. (No year indicated).

3. Internet Access. Osteophorosis overview. National Institutes of Health. Revised Date: Sept, 2002.
4. Internet Access. Topics in Osteophorosis: Alcohol and Bone Health. National Institutes of Health. Revised Date: Ilug, 2001.

5. Internet Access. Nutrition and the Skeleton: The Role of Calcium and Other Nutrients. National Institutes of Health. Revised Date: Aug, 2001.

6. Internet Access. Osteophorosis in Men. National Institutes of Health. Revised Date: Oct, 2001.

7. Internet Access. Smoking and Bone Health. National Institutes of Health. Revised Date: July, 1999.

8. Internet Access. Calcium and Osteophorosis Prevention. Based on NOF's Quarterly Member Newsletter, Osteoporosis Report, Spring 1999. 